\title{
Update on oral Chagas disease outbreaks in Venezuela: epidemiological, clinical and diagnostic approaches
}

\author{
Belkisyolé Alarcón de Noya ${ }^{1,2} /{ }^{+}$, Zoraida Díaz-Bello', Cecilia Colmenares ${ }^{1,2}$, Raiza Ruiz-Guevara², \\ Luciano Mauriello', Arturo Muñoz-Calderón', Oscar Noya ${ }^{1,2,3,4}$

\begin{abstract}
'Sección de Inmunología ${ }^{3}$ Sección de Biohelmintiasis, Instituto de Medicina Tropical ${ }^{2}$ Cátedra de Parasitología, Escuela de Medicina Luís Razetti, Facultad de Medicina, Universidad Central de Venezuela, Caracas, Venezuela ${ }^{4}$ Centro para Estudios sobre Malaria, Instituto de Altos Estudios Dr Arnoldo Gabaldón,

Instituto Nacional de Higiene Rafael Rangel, Ministerio del Poder Popular para la Salud, Caracas, Venezuela
\end{abstract}

\begin{abstract}
Orally transmitted Chagas disease has become a matter of concern due to outbreaks reported in four Latin American countries. Although several mechanisms for orally transmitted Chagas disease transmission have been proposed, food and beverages contaminated with whole infected triatomines or their faeces, which contain metacyclic trypomastigotes of Trypanosoma cruzi, seems to be the primary vehicle. In 2007, the first recognised outbreak of orally transmitted Chagas disease occurred in Venezuela and largest recorded outbreak at that time. Since then, 10 outbreaks (four in Caracas) with 249 cases (73.5\% children) and 4\% mortality have occurred. The absence of contact with the vector and of traditional cutaneous and Romana's signs, together with a florid spectrum of clinical manifestations during the acute phase, confuse the diagnosis of orally transmitted Chagas disease with other infectious diseases. The simultaneous detection of IgG and IgM by ELISA and the search for parasites in all individuals at risk have been valuable diagnostic tools for detecting acute cases. Follow-up studies regarding the microepidemics primarily affecting children has resulted in $70 \%$ infection persistence six years after anti-parasitic treatment. Panstrongylus geniculatus has been the incriminating vector in most cases. As a food-borne disease, this entity requires epidemiological, clinical, diagnostic and therapeutic approaches that differ from those approaches used for traditional direct or cutaneous vector transmission.
\end{abstract}

Key words: Chagas disease - oral transmission - outbreaks - Venezuela

Chagas disease or American trypanosomiasis is considered the parasitosis with a great economic burden in Latin America due to its prolonged chronicity, which is associated with poverty and poor housing conditions (WHO 2007, 2010). Despite all efforts to control vector and transfusion transmission, Chagas disease still represents a health threat for the 108 million exposed people living in 21 countries where Chagas disease is endemic (OPS/OMS 2006). In 2006, the Pan American Health Organization estimated that Chagas disease affected 7.6 million (OPS/ OMS 2006) and, in 2009, the figures were 12-14 million people, with an annual incidence of 200,000 cases (OPS 2009). The persistence of Chagas disease is based on the various transmission mechanisms of Trypanosoma cruzi. A new epidemiological scenario in terms of nonvector transmission (congenital route) occurs in nonendemic countries due to migration (Gascón et al. 2010, Rassi Jr et al. 2010). In Latin America, several outbreaks of oral-

doi: 10.1590/0074-02760140285

Financial support: FONACIT (2012001295) (Biomarcadores para la vigilancia de la curación de los pacientes con Enfermedad de Chagas de transmisión oral de las comunidades de Chacao, Chichiriviche y Antímano)

+ Corresponding author: belkisyole@gmail.com

Received 8 August 2014

Accepted 25 February 2015 ly transmitted Chagas disease have been reported since 1968 and these outbreaks have been the primary sources of acute cases in the Amazon Basin (Coura 2006).

The following possible mechanisms for orally transmitted Chagas disease have been postulated. (i) Contamination of food, drinks, fruits and juices with the faeces of infected triatomines prepared in areas where humans have invaded the ecological niche and where the enzootic vector-reservoir cycle occurs. This mechanism, which has been experimentally confirmed (Lainson et al. 1980, Cardoso et al. 2006, Añez et al. 2009), was most likely involved in the state of Amapá, Brazil, outbreak that occurred in 1999 (Valente et al. 2009). (ii) Direct consumption of $T$. cruzi-infected vectors. Diaz-Ungría (1965) demonstrated this mechanism in laboratory animals through biological vectors such as triatomines and mechanic vectors such as Musca domestica. (iii) Consumption of food contaminated with urine or marsupial scent gland secretions containing metacyclic trypomastigotes of T. cruzi (Jansen \& Deane 1985). (iv) Ingestion of raw or undercooked hunting meat. Thomas et al. (2007) found infection in Phyllostomus sp. (bats) after these bats ingested T. cruzi-infected mice; however, Roellig et al. (2009) did not detect infection by this same mechanism in raccoons. (v) Consumption of the blood of wild animals during religious rituals or folk medicine in some rural and jungle areas of the continent (OPS 2009, Alarcón de Noya et al. 2010c). (vi) Breast-feeding (Mazza et al. 1936). Despite confirmed experimental infection in mice and discovered trypomastigotes in milk, infection through this mechanism does not seem to be efficient (Miles 1972, Norman \& López-Velez 2013). 


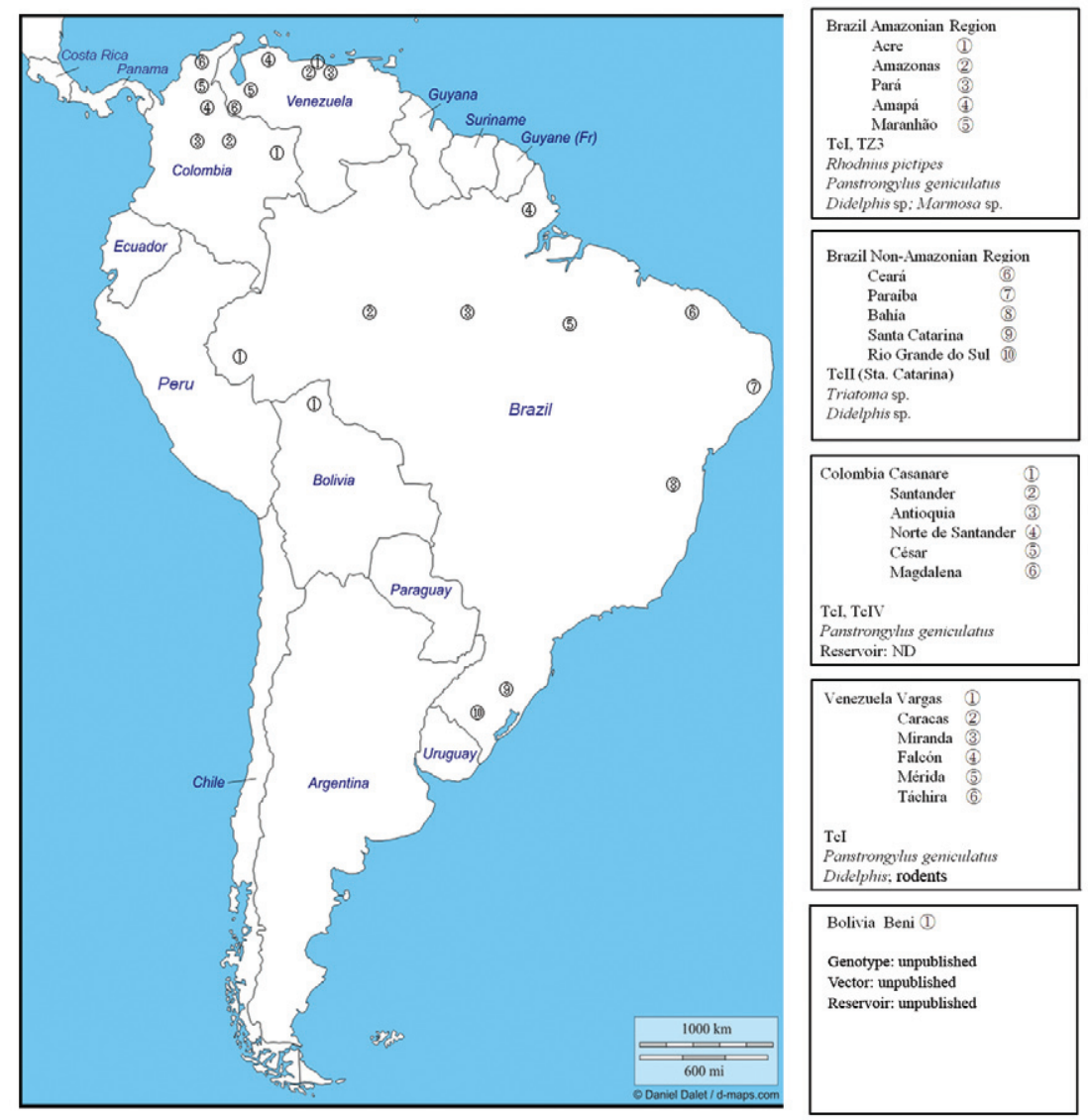

Fig. 1: geographical distribution of oral transmitted Chagas disease outbreaks occurred in America: Brazil Amazonian Region [1: Acre (SVS 2011); 2: Amazonas (SVS 2011); 3: Pará (Valente et al. 2001, Beltrão et al. 2009, Nóbrega et al. 2009); 4: Amapá (Pinto et al. 2008, SVS 2011); 5: Maranhão (Pinto et al. 2008)], Brazil Non-Amazonian Region [6: Ceará (Cavalcanti et al. 2009); 7: Paraiba (Shikanai-Yasuda 1987); 8: Bahia (Maguire et al. 1986); 9: Santa Catarina (Steindel et al. 2008); 10: Rio Grande do Sul (Nery-Guimarães et al. 1968)], Colombia [1: Casanare (ProMED-mail 2014); 2: Santander (Hernández et al. 2009); 3: Antioquía (Ríos et al. 2011); 4: Norte de Santander (Bohórquez et al. 1992); 5: César (ProMED-mail 2010b); 6: Magdalena (Cáceres et al. 1999)], Venezuela [1: Vargas (Alarcón de Noya \& Martínez 2009); 2: Caracas (Alarcón de Noya et al. 2010b, ProMED 2010a, 2012); 3: Miranda (2014, unpublished observations); 4: Falcón (2013, unpublished observations); 5: Mérida (Añez et al. 2013); 6: Táchira (Benítez et al. 2013, 2014, unpublished observations)] and Bolivia [1: Beni (Santalla-Vargas et al. 2011)].

The study of orally transmitted Chagas disease should be analysed under different perspectives:

An epidemiological approach - Oral T. cruzi transmission can occur in rural and urban places. In rural areas, the contamination of food/beverages by domiciliated, peridomestic or sylvatic vectors has the usual vector control measures. Orally transmitted Chagas disease transmission that occurs in urban areas is usually derived from travelling infected triatomines. An example of this transmission occurred in the city of Belém, Brazil, namely, an epidemiological situation of distantiae transmission (Xavier et al. 2014) or the consumption of contaminated drinks such as the Chacao episode (Alarcón de Noya et al. 2010a). The absence of direct contact with the vector is one of the primary factors that has confounded clinicians and epidemiologists, guiding the initial diagnosis to other common entities of tropical and temperate areas of America (e.g., dengue, malaria, mononucleosis and leptospirosis).
A clinical approach - Traditional cutaneous and/or ocular inflammatory signs are not present and the clinical manifestations in the acute phase tend to be more severe compared to Chagas disease acquired by direct dermal or mucosal contact with the vector. Furthermore, whether the clinical course of the chronic phase of the disease and response to treatment differ from those of individuals infected through the classical vector mechanism is unknown.

A laboratory diagnostic approach - Regarding infection acquisition, a large group of people can most likely be infected simultaneously, which occurred in the orally transmitted Chagas disease microepidemics in Venezuela (Alarcón de Noya \& Martínez 2009, Alarcón de Noya et al. 2010a). Diagnostic methods that provide rapid and accurate results for immediate treatment are need (OPS 2009, Alarcón de Noya et al. 2012).

A therapeutic approach - Based on the persistence of infection, as determined by polymerase chain reaction (PCR) and/or by haemoculture in some cases, as well as 


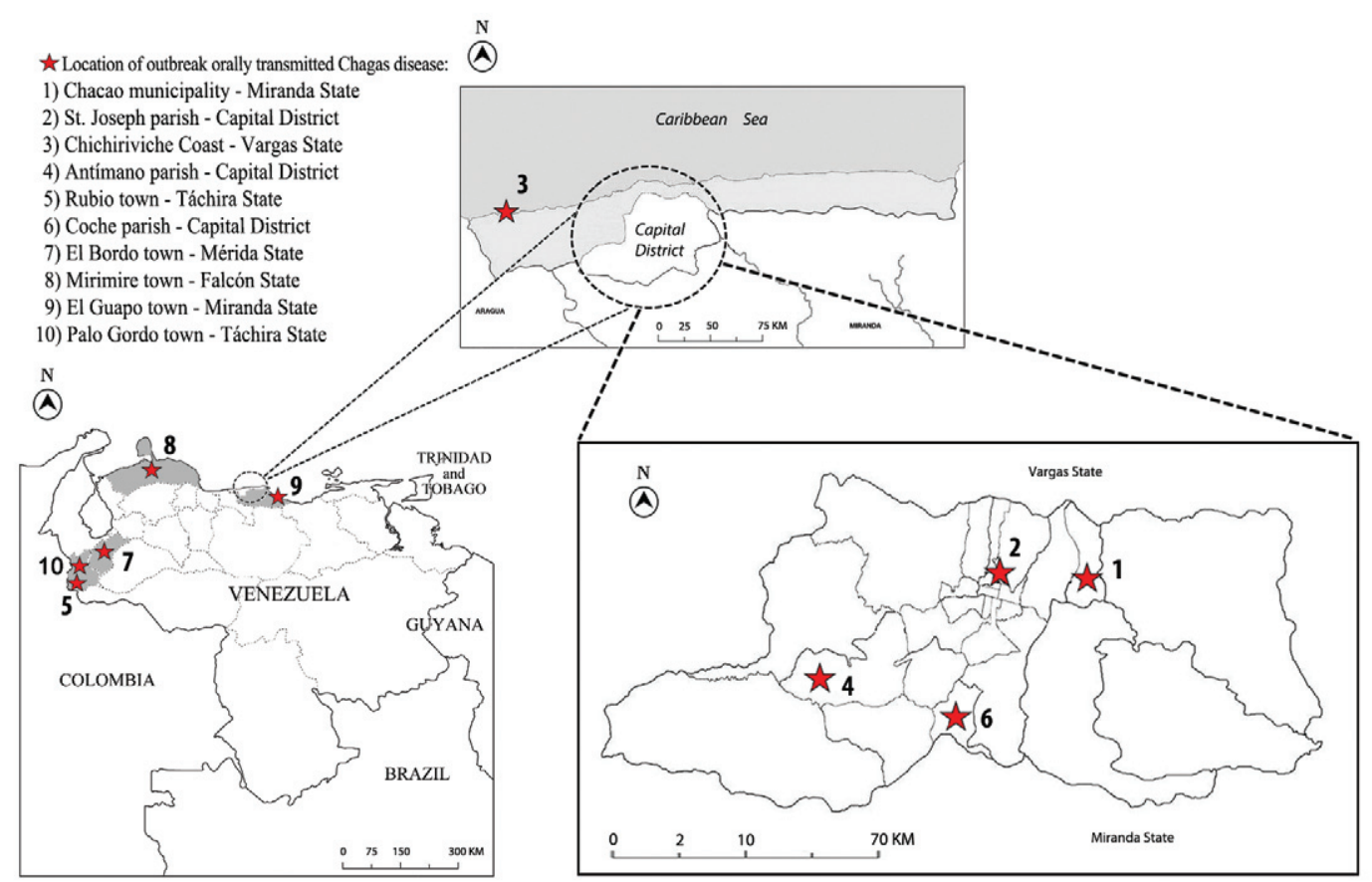

Fig. 2: geographical distribution of oral transmitted Chagas disease outbreaks occurred in Venezuela (for references see Table I).

by lytic antibodies, a high rate of treatment failure has occurred in these patients during follow up (Alarcón de Noya et al. 2011). Whether this failure is related to the way of disease acquisition, which might cause higher parasitaemia, is unknown because we have not found in vitro evidence that these parasites are resistant to the traditional antiparasitic drugs (Muñoz-Calderón et al. 2012). Six discrete typing unit (DTU) genotypes of the parasite from different endemic regions have been identified; these genotypes are most likely involved in the various clinical manifestations, disease severity (Zingales et al. 2012) and drug resistance.

The oral transmission of Chagas disease has been known since the first identified outbreak in the city of Teutônia (state of Rio Grande do Sul, Brazil) (NeryGuimarães et al. 1968). Since then, the SAS Valente group has studied the Brazilian outbreaks and has attributed 196 episodes to oral transmission (SAS Valente, unpublished observations). The possible vehicles of oral transmission have been açaí (Valente et al. 1999) and sugar cane juices (Cardoso et al. 2006). The majority of outbreaks have occurred in the Amazon Basin, in small families or related groups of few individuals, with Rhodnius pictipes and Panstrongylus geniculatus, the primary incriminated vectors of these outbreaks. In Colombia, the first report of this disease was in 1992 and 14 military personnel were infected (Bohórquez et al. 1992). Eight outbreaks have been published since then (Fig. 1), with the largest and last outbreak occurring in Casanare, affecting 31 people (ProMED 2014). In chronological order, Venezuela is the third country with orally transmitted Chagas disease reports since 2007 (Alarcón de Noya et al. 2010a) and Bolivia is the fourth (Santalla-Vargas et al. 2011). Fig. 1 shows the geographical distribution of several orally transmitted Chagas disease outbreaks that have occurred in America, noting the vectors and the predominant genotypes of T. cruzi involved. Detailed reviews of orally transmitted Chagas disease cases in Brazil and the epidemiological aspects of orally transmitted Chagas disease have been published elsewhere (Valente et al. 1999, Coura 2006, Pereira et al. 2013).

In this paper, we review the orally transmitted Chagas disease outbreaks that have occurred in Venezuela and provide recommendations from these incidences.

\section{Outbreak records in Venezuela}

Orally transmitted Chagas disease cases have occurred in the north-central coastal and western regions of Venezuela (Fig. 2). Their georeferences, the numbers of infected individuals and mortality are shown in chronological order in Table I. Brief descriptions of the 10 episodes are presented below.

Chacao, Caracas - In December 2007, one trypomastigote of T. cruzi was found in a blood smear from a girl referred to the University Hospital of Caracas (HUC) (Martín et al. 2009). The link to the first microepidemic known in the country was made by the appearance of a second case, a teacher that worked at the same school where the girl studied (Alarcón de Noya et al. 2010b). From that moment, a wide screening was performed on 1,000 individuals in the school, including people who were in charge of preparing artisanal snacks and juices. One hundred and two individuals were infected, as well as the lady who prepared the breakfast in a neighbourhood $6 \mathrm{~km}$ away from the school, where T. cruzi-infected P. geniculatus, rodents and dogs were demonstrated (Alarcón de Noya et 
TABLE I

Outbreaks of oral transmitted Chagas disease in Venezuela

\begin{tabular}{|c|c|c|c|c|c|c|c|c|}
\hline Locality & Georeference & Date & $\begin{array}{l}\text { Patients } \\
\text { (n) }\end{array}$ & $\begin{array}{l}\text { Adults } \\
\text { (n) }\end{array}$ & $\begin{array}{l}\text { Children } \\
\text { (n) }\end{array}$ & $\begin{array}{l}\text { Mortal } \\
\mathrm{n}(\%)\end{array}$ & $\begin{array}{l}\text { Probable } \\
\text { source }\end{array}$ & References \\
\hline $\begin{array}{l}\text { Chacao, } \\
\text { Caracas, DF }\end{array}$ & $\begin{array}{l}10^{\circ} 29 ' 39.77^{\prime \prime} \mathrm{N} \\
66^{\circ} 51^{\prime} 12.07 ’ \mathrm{~W}\end{array}$ & $\begin{array}{l}\text { December } \\
2007\end{array}$ & 103 & 26 & 77 & $1(1)$ & $\begin{array}{l}\text { Guava } \\
\text { juice }\end{array}$ & $\begin{array}{l}\text { Alarcón de Noya et al. } \\
(2010 \mathrm{a}, \mathrm{b}, \mathrm{c})\end{array}$ \\
\hline $\begin{array}{l}\text { San José, } \\
\text { Caracas, DF }\end{array}$ & $\begin{array}{l}10^{\circ} 29 ' 51.95 ” \mathrm{~N} \\
66^{\circ} 544^{\prime} 16.511^{\prime \prime} \mathrm{W}\end{array}$ & $\begin{array}{l}\text { May } \\
2008\end{array}$ & 3 & 2 & 1 & $0(0)$ & Unknown & Unpublished \\
\hline $\begin{array}{l}\text { Chichiriviche, } \\
\text { Vargas }\end{array}$ & $\begin{array}{l}10^{\circ} 31^{\prime} 53.97 ” \mathrm{~N} \\
67^{\circ} 15^{\prime} 36.02^{\prime \prime} \mathrm{W}\end{array}$ & $\begin{array}{l}\text { March } \\
2009\end{array}$ & 89 & 9 & 80 & $5(5.6)$ & $\begin{array}{l}\text { Guava } \\
\text { juice }\end{array}$ & $\begin{array}{l}\text { Alarcón de Noya and Martínez } \\
\text { (2009) }\end{array}$ \\
\hline $\begin{array}{l}\text { Antímano, } \\
\text { Caracas, DF }\end{array}$ & $\begin{array}{l}10^{\circ} 28^{\prime} 01.53^{\prime \prime} \mathrm{N} \\
66^{\circ} 59^{\prime} 15.48^{\prime \prime} \mathrm{W}\end{array}$ & $\begin{array}{l}\text { May } \\
2010\end{array}$ & 22 & 5 & 17 & $1(4.5)$ & $\begin{array}{l}\text { Passion fruit } \\
\text { juice }\end{array}$ & $\begin{array}{l}\text { ProMED } \\
(2010 a, b)\end{array}$ \\
\hline $\begin{array}{l}\text { Rubio, } \\
\text { Táchira }\end{array}$ & $\begin{array}{c}7^{\circ} 42^{\prime} 00^{\prime \prime} \mathrm{N} \\
72^{\circ} 20^{\prime} 60.00^{\prime} \mathrm{W}\end{array}$ & $\begin{array}{l}\text { November } \\
2010\end{array}$ & 7 & 4 & 3 & $1(14.3)$ & Unknown & $\begin{array}{l}\text { Benítez et al. } \\
\text { (2013) }\end{array}$ \\
\hline $\begin{array}{l}\text { Coche, } \\
\text { Caracas, DF }\end{array}$ & $\begin{array}{l}10^{\circ} 26^{\prime} 54.07 ’ \mathrm{~N} \\
66^{\circ} 55^{\prime} 28.30^{\prime \prime} \mathrm{W}\end{array}$ & $\begin{array}{l}\text { March } \\
2012\end{array}$ & 4 & 4 & 0 & $0(0)$ & Unknown & $\begin{array}{l}\text { ProMED } \\
(2012)\end{array}$ \\
\hline $\begin{array}{l}\text { El Bordo, } \\
\text { Mérida }\end{array}$ & $\begin{array}{l}8^{\circ} 25^{\prime} 40.92 ” \mathrm{~N} \\
71^{\circ} 35^{\prime} 54.62 ” \mathrm{~W}\end{array}$ & $\begin{array}{l}\text { July } \\
2012\end{array}$ & 5 & 2 & 3 & $1(20)$ & Unknown & $\begin{array}{l}\text { Añez et al. } \\
\text { (2013) }\end{array}$ \\
\hline $\begin{array}{l}\text { Mirimire, } \\
\text { Falcón }\end{array}$ & $\begin{array}{l}11^{\circ} 99^{\prime} 45.48^{\prime \prime} \mathrm{N} \\
68^{\circ} 433^{\prime} 33.35^{\prime} \mathrm{O}\end{array}$ & $\begin{array}{l}\text { June } \\
2013\end{array}$ & 8 & 8 & 0 & $1(12.5)$ & $\begin{array}{l}\text { Mango } \\
\text { juice }\end{array}$ & Unpublished \\
\hline $\begin{array}{l}\text { El Guapo, } \\
\text { Miranda }\end{array}$ & $\begin{array}{l}10^{\circ} 8^{\prime} 48.45^{\prime \prime} \mathrm{N} \\
65^{\circ} 58^{\prime} 13.89 ” \mathrm{O}\end{array}$ & $\begin{array}{l}\text { February } \\
2014\end{array}$ & 3 & 2 & 1 & $0(0)$ & $\begin{array}{l}\text { Pumarosa } \\
\text { juice }\end{array}$ & Unpublished \\
\hline $\begin{array}{l}\text { SanCristobal, } \\
\text { Táchira }\end{array}$ & $\begin{array}{c}7^{\circ} 48^{\prime} 36.18^{\prime \prime} \mathrm{N} \\
72^{\circ} 12^{\prime} 20.077^{\prime} \mathrm{O}\end{array}$ & $\begin{array}{l}\text { July } \\
2014\end{array}$ & 5 & 4 & 1 & $0(0)$ & Unknown & Unpublished \\
\hline Total & - & - & 249 & 66 & 183 & $10(4)$ & - & - \\
\hline
\end{tabular}

al. 2010a, Díaz-Bello et al. 2011). This outbreak has been the largest known outbreak by far (Miles 2010).

San José, Caracas - In May 2008, a couple with febrile syndrome, husband ( 29 years old) and wife ( 26 years old) were referred to the Centre for Studies in Malaria in Caracas to exclude Plasmodium falciparum infection. After clinical and laboratory evaluations, this initial diagnosis was discarded; however, the woman's facial and lower limb oedema led to the clinical suspicion that orally transmitted Chagas disease was the diagnosis. The aetiology for T. cruzi was confirmed by serological, parasitological and PCR tests. The two-year-old son was positive for T. cruzi as determined by parasitological and serological assays, but unexpectedly negative by PCR assay. The husband required hospitalisation due to severe arrhythmia and pericarditis. The simultaneous occurrence of these three acute cases and the lack of parasite skin or mucosa entrance suggested oral infection. $P$. geniculatus was captured in their house.

Chichiriviche de la Costa, Vargas State - In March 2009, the Vargas State epidemiologist collected blood samples from patients with prolonged fever from a rural town at the seashore. All samples, which were evaluated at the Institute of Tropical Medicine (IMT), revealed positive anti-T. cruzi IgG and IgM. Parasites were observed in the fresh blood smears of some individuals. The authorities of the Ministry of Health created a sanitary cordon, preventing their displacement, and performed a serological screening of the entire population $(n=441)$. Eightyeight orally transmitted Chagas disease cases (teachers, students, cooks and administrative staff) were related to the local school (Alarcón de Noya \& Martínez 2009). Four individuals died; one of them was a young pregnant woman (cafeteria cook) with a large pericardial effusion and systemic parasite invasion (Suárez et al. 2010).

Antímano, Caracas - In May 2010, the influx of several children with prolonged fever with facial oedema made paediatricians of the Miguel Pérez Carreño Hospital, in Caracas, suspect orally transmitted Chagas disease. Of the samples tested at the IMT, 20 were positive for specific $\operatorname{IgG}$ and $\operatorname{IgM}$ and the presence of parasites was demonstrated. An 18-month-old child died before treatment (ProMED 2010a, b).

Rubio, Táchira State - In October 2010, a trypomastigote was observed in the peripheral blood of a two-year-old child 16 days after admission for pneumonia in Táchira. During hospitalisation, she developed fever, pericarditis, lower limb oedema, ascites and hepatosplenomegaly before receiving treatment. Five relatives were also diagnosed and required hospitalisation. $P$. geniculatus was incriminated (Benítez et al. 2013). The father of this family consulted the IMT during the acute phase when the presence of the parasite was demonstrated. Thus, we suggest that this outbreak included seven infected people. 
Coche, Caracas - In March 2012, the medical team at the Medicine I Service of the HUC suspected that two men with prolonged febrile syndrome had acute Chagas disease. Mobile trypomastigotes were observed by the microhaematocrit technique (Freilij et al. 1983) and their sera were positive for IgG and IgM. Four workers remodelling a room in the Coche market in Caracas were diagnosed with extremely high parasitaemia (ProMED 2012). The rats infected with $T$. cruzi were captured on site, but no triatomines were found.

El Bordo, Mérida State - In July 2012, trypomastigotes of $T$. cruzi were demonstrated in the blood of five severely affected patients from the rural town of El Bordo. One adult died with acute myocarditis. The presence of cattle, pigs and a dog and the frequent visit of rodents and Didelphis to peridomestic housing were found. Triatoma maculata and $P$. geniculatus were found inside the house and Rhodnius prolixus and Eratyrus mucronatus were found during the entomological inspection of the neighbouring houses. T. cruzi was found only in $P$. geniculatus (Añez et al. 2013).

Mirimire, Falcón State - In June 2013, we diagnosed an acute Chagas disease case in a 16-year-old male hospitalised in Caracas while searching for febrile antigens and leptospirosis. The serology was positive for T. cruzi and high parasitaemia was evident. This patient had eight relatives with similar symptoms who were also diagnosed with acute Chagas disease cases. A young puerperal woman died a few days after starting antiparasitic treatment. P. geniculatus was collected in the house where mango juice was prepared and offered to these individuals, including the deceased.

El Guapo, Miranda State - In February 2014, a cardiologist suspected an acute case of Chagas disease in a 16year-old patient from the town of El Guapo. This patient had prolonged febrile syndrome, a large pericardial effusion and myocarditis and was hospitalised at the Military Hospital in Caracas. Positive serology and parasitaemia were demonstrated. His parents reported fever for a few days and died simultaneously with their son. Both IgG and IgM were also positive in these two relatives.

San Cristobal, Táchira State - On 25 July 2014, an orally transmitted Chagas disease outbreak affected five individuals in a family ( 1 child and 4 adults). Three of them were hospitalised with myocarditis.

\section{Other possible outbreaks due to oral transmission}

San Juan de los Morros, Guárico State - In 2005, seven individuals died with acute myocarditis and positive serology for Chagas disease. All lived in a nursing home. Gathering evidence regarding the transmission of infection was not possible. This episode was published in newspapers, but not in scientific journals. Guárico is one of the endemic states for Chagas disease; therefore, in retrospect, the concurrency of acute cases with high mortality arising in the same habitat or institution suggests that this incident was an oral outbreak of T. cruzi.

Barinas State - Añez et al. (2007) published nine acute cases from Barinas and Trujillo, including two deaths. Upon reviewing these episodes with the author, orally transmitted Chagas disease most likely occurred in four of the cases in Barinas because the infected individuals lived in the same household and because the clinical manifestations were simultaneous. The bilateral palpebral oedema, which was one of the general symptoms displayed by the patients, was registered as Romana's sign, but did not correspond to entrance point of the parasites. The two acute Chagas disease cases from Trujillo could also be due to oral transmission because both had consumed cane juice and had no evidence of skin entrance by the parasite.

\section{Diagnostic approach and outbreak monitoring}

Once an acute case occurs in which epidemiologists and clinicians suspect oral transmission of T. cruzi, the next step is the identification of all individuals at risk to proceed to the diagnosis and treatment immediately to prevent any fatal outcome.

Background - The interview of the suspected patient should be directed towards the investigation of food habits, the ingestion of homemade fruit juices, the habit of sharing meals with family or neighbours living around the index case, the place and hygienic conditions where food is prepared and the possibility that insects or small mammals enter the pantry or the kitchen where food is stored. Identifying the person who runs the kitchen is important for obtaining key information regarding his/her health, how food/ beverages were processed and stored (particularly artisan natural juices), the use of appropriate containers to store and prepare (blenders) the juices and whether any insect has been observed inside. Questions regarding the presence of bugs, rats or other type of animals must be performed. Knowledge regarding other related individuals who are ill with similar symptoms is also important.

Clinical diagnosis - Clinical manifestations are variable among patients during orally transmitted Chagas disease outbreaks (Alarcón de Noya et al. 2010a) and this variation is likely to depend on not only the immune response, but also the size of the inoculum. In Chacao, for example, most people started with a high fever for five-10 days after the suspected week of infection and a death occurred 40-45 days later. In other cases, the fever came later or symptoms were milder and others showed no symptoms at all. The selection of individuals to be investigated cannot be limited to those individuals with symptoms.

Unexplained high and prolonged fever is the dominant sign of infection; however, headache, weakness and facial oedema can occur independent of fever. Acute cardiomyopathy with arrhythmia and pericardial effusion was the reason for the hospitalisation of 22 patients during the Chacao outbreak (Alarcón de Noya et al. 2013). No entrance inflammation sign was observed in this group of patients (chagoma and/or Romana's signs) and these individuals denied contact with triatomines. The occurrence of arrhythmia, pericardial effusion and cardiomegaly with unknown causality should also suggest acute Chagas disease (Pinto et al. 2008, OPS 2009, Alarcón de Noya et al. 2010a, Añez et al. 2013, Benítez et al. 2013). 
TABLE II

Clinical forms of oral transmitted Chagas disease outbreaks in Venezuela

\begin{tabular}{lcccc}
\hline & & \multicolumn{3}{c}{ Clinical classification } \\
\cline { 3 - 5 } Community & $\begin{array}{c}\text { Patients } \\
\text { (n) }\end{array}$ & $\begin{array}{c}\text { Asymptomatic } \\
\mathrm{n}(\%)\end{array}$ & $\begin{array}{c}\text { Mild or moderate } \\
\text { symptoms } \\
\mathrm{n}(\%)\end{array}$ & $\begin{array}{c}\text { Severe } \\
\text { symptoms }{ }^{a} \\
\mathrm{n}(\%)\end{array}$ \\
\hline Chacao, Caracas, DF & 103 & $16(15.5)$ & $67(65.1)$ & $20(19.4)$ \\
San José, Caracas, DF & 3 & $1(33.3)$ & $1(33.3)$ & $1(33.3)$ \\
Chichiriviche, Vargas & 89 & $7(7.9)$ & $9(10.1)$ & $73(82)$ \\
Antímano, Caracas, DF & 22 & $\mathrm{UP}$ & $\mathrm{UP}$ & $\mathrm{UP}$ \\
Rubio, Táchira & 7 & $1(14.3)$ & $0(0)$ & $6(85.7)$ \\
Coche, Caracas, DF & 4 & $0(0)$ & $0(0)$ & $4(100)$ \\
El Bordo, Mérida & 5 & $0(0)$ & $0(0)$ & $5(100)$ \\
Mirimire, Falcón & 8 & $0(0)$ & $5(62.5)$ & $3(37.5)$ \\
El Guapo, Miranda & 3 & $2(66.7)$ & $0(0)$ & $1(33.3)$ \\
San Cristóbal, Táchira & 5 & $2(40)$ & $0(0)$ & $3(60)$ \\
\hline Total & 249 & $29 / 227(12.7)$ & $82 / 227(36.1)$ & $116 / 227(51.1)$ \\
\hline
\end{tabular}

a: includes dead patients; UP: unpublished observations.

We clinically classify patients with acute orally transmitted Chagas disease as follows: group 1, asymptomatic patients, group 2, patients with mild or moderate symptoms whose clinical situation allowed them to continue with school or work activities, and group 3, patients whose symptoms prevented them to continue their routine and who were confined to their houses, hospitalised or died. Based on this classification, Table II summarises the clinical forms of patients during orally transmitted outbreaks in Venezuela.

The overall mortality during the outbreaks included three adults, six children and one stillborn and its distribution is shown in Table I. In this group, two young women died, one during pregnancy and the other during the puerperal period.

Laboratory diagnosis - In almost all outbreaks, the identification of index cases occurred fortuitously in patients with prolonged high fever without an apparent cause. The frequent presumptive diagnosis of malaria derived from searching for parasites in stained smears where trypomastigotes of T. cruzi were found. Simultaneous serological diagnosis based on the detection of IgG and IgM by ELISA has been the most effective tool and has been used as a first screening approach to identify infected individuals. The second confirmation technique [indirect haemagglutination (IHA) or immunofluorescence] can be performed later on. Ideally, three blood samples should be requested initially: one tube without anticoagulant for serology, one heparin tube for culture, microhaematocrit and animal inoculation (Freilij et al. 1983, Luquetti \& Rassi 2000) and one tube with ethylenediamine tetraacetic acid for PCR (Schijman et al. 2011). The first outbreak, which has been the largest, was addressed by massive serology (IgG and IgM ELISA and IHA). Based on the initial results, second samples from some individuals were evaluated by in vitro culture and PCR. Hence, identifying the parasite in all patients was not possible, except for the first group of school teachers and the girl index case (Alarcón de Noya et al. 2010a, 2012). In subsequent outbreaks handled at the IMT, the three above-recommended samples have been collected initially from all people at risk of infection. The methodology and results have been described elsewhere (Alarcón de Noya et al. 2013).

General laboratory tests should include routine haematology, blood chemistry, troponin and C-reactive protein. In 19 confirmed cases that were hospitalised during the Chacao outbreak, eight/11 had troponin alterations, eight/14, high erythrocyte sedimentation rate, 14/16, positive C-reactive protein, eight/nine, lactate dehydrogenase, and eight $/ 19$, leukocytosis (Alarcón de Noya et al. 2013). During the ingestion of the antiparasitic treatment, consultations should be performed weekly or every 15 days not only to oversee the administration of the drug and its dose, but also for clinical and laboratory adverse effects, such as increased liver enzymes and bilirubin (Castro et al. 2006). Once the treatment is complete, serology, culture and PCR tests should be performed at least every six months and then annually, monitoring the evolution, as well as electrocardiogram, echocardiogram and Holter for cardiac evaluation.

In the two school outbreaks, monitoring has been rigorous and based on complementary laboratory tests: complement-mediated lysis and PCR. Unfortunately, after five-six years of treatment, $70 \%$ of both groups still have positive lytic antibodies and some of these individuals still have positive PCR results. Although both groups are primarily composed of children, treatment was supervised and applied during the acute phase (Alarcón de Noya et al. 2011). A study was conducted to quantify the parasite burden in 16 cases of infection in the Chacao group. In total, 14 patients were positive as determined by quantitative PCR assay before treatment $(87.5 \%)$ and 
the parasitic loads ranged between 1.69-5.23 $\log _{10}$ par. eq./10 mL of blood, which is consistent with the expected results observed under acute infections. In assessing drug efficacy, post-treatment samples revealed a high level of therapeutic failure, as mentioned previously, implying that these patients are progressing to the chronic stage of the disease (Duffy et al. 2013). Because in vitro susceptibility tests of parasite isolates have shown the absence of resistance to benznidazole and nifurtimox (Muñoz-Calderón et al. 2012), a second treatment was administered to those individuals with persisting high levels of lytic antibodies and/or positive PCR results.

\section{Epidemiological characteristics}

In Venezuela, two types of oral infection with $T$. cruzi have occurred. Those infections that occurred in the schools were identified as microepidemics, where the number of affected individuals is numerous and outbreaks of small groups, for example, families. Therefore, 10 outbreaks have occurred: two microepidemics (Chacao and Chichiriviche) and eight outbreaks of small groups. Individual orally transmitted Chagas disease cases are likely occurring because we frequently diagnose individuals with specific antibodies for T. cruzi, as demonstrated by several techniques, who have never been bitten by triatomines, have not left Caracas, have not received transfusions and whose mothers are negative for this entity.

As a vehicle, the intake of homemade seasonal fruit juices is a common denominator in the testimony during the clinical and epidemiological questionnaire. The method of preparation of guava juice was identical for the two school microepidemics. A large amount of guavas was boiled the day before and allowed to cool overnight in open containers. Early in the morning, the guavas were liquefied for juice preparation. The contamination of solid foods is possible and may trigger single T. cruzi infections; however, when the contamination of beverages occurs, a greater number of individuals are at risk for infection. Another extremely common situation in this country is the sale of homemade beverages in the street without any sanitary control. Street vendors even offer artisanal cold drinks to drivers on roads.

In all entomological studies where triatomines were found, the predominant vector was $P$. geniculatus (Alarcón de Noya et al. 2010a, Añez et al. 2013), including the Táchira outbreak, where Rhodnius, Triatoma and Eratyrus were also found (Benítez et al. 2013). Although $P$. geniculatus is a triatomine with a retarded defecation reflex, several studies have suggested that $P$. geniculatus is the vector in the capital region in Venezuela (ReyesLugo 2009) that is also infected with T. cruzi in 50\% of captured individuals (Carrasco et al. 2005). P. geniculatus has been found domiciled; this insect is best suited for urban conditions after humans invaded, burned and deforested their original environments (Reyes-Lugo 2009). Patients generally deny the presence of bugs in their houses or schools. A systematic, deep and conscious search of triatomines, with the participation of each community, is recommended.

Parasites - Three molecular markers (mini-exon and domain 24SA and 18S ribosomal RNA genes) were used to characterise T. cruzi from patients, reservoirs and vec- tors involved in five episodes of orally transmitted Chagas disease outbreaks. All parasite isolates involved in the different studied oral outbreaks were identified as DTU I (TcI) (Muñoz-Calderón et al. 2013), which is the most common lineage in Venezuela (Carrasco et al. 2012).

By analysing the intergenic region of the mini-exon gene cloning these products and their subsequent sequencing, the presence of different genotypes (DTU I SL-IR) was studied. Parasite isolates showed haplotype (Herrera et al. 2009) heterogeneity because TcI haplotype d (TCId) occurred in $68.7 \%$, while the remaining $31.3 \%$ was represented by a mixture of microsatellite motif SL-IR groups (18.8\% were TcId $+\mathrm{TcIb}$ and $12.5 \%$ TcId + TcIa). The populations of haplotypes TcIb, TcIa and mixtures (TcId + TcIb, TcId + TcIa and TcIb + TcIa) are recurrent in isolates obtained from children. Furthermore, the SL-IR analysis showed two clones representing a possible hybrid between TcIa and TcIb (haplotype TcIa/Ib) (Muñoz-Calderón et al. 2013).

The genotypes of parasite isolates from humans infected in Chacao and of triatomines and rats captured in the place of preparation of guava juice were identified as TcId (Muñoz-Calderón et al. 2013, Díaz-Bello et al. 2014). All the parasites isolates belonged to lineage I and when the multiple sequence analysis of the mini-exon was performed, the mini-exon was determined to be identical. The similarity of the parasites isolated from the oral urban population outbreak with the triatomines and rats captured suggest a common origin (Díaz-Bello et al. 2014).

\section{Consequences}

In addition to the general consequences of infection by T. cruzi, such as the evolution to the chronic phase, an unpredictable cure with the chance of developing heart disease and the inability to donate blood and organs, sector-specific consequences also occur. For example, in small towns such as Chichiriviche, where 88 people were infected, 79 of which were under 16 years old, means a cohort of young Chagas disease-infected individuals on whose shoulders will rest the local economy in the near future.

The children are now teenagers and have begun to disperse and form new households. Despite multiple conversations, many of these teenagers are unaware that they remain infected. The primary concern is for those teenagers who will soon begin their sexual life, with the probability of having babies with congenital Chagas disease.

\section{Control measures and authors' recommendations}

Vector control based on indoor spraying in risk areas continues to be a basic measure. Given the frequency of oral transmission, surveillance must also aim at food safety, particularly at the institutional level (schools, orphanages, universities, nursing homes, canteens, restaurants and street sales of juices/food). The domiciliation of a former strict wild vector such as P. geniculatus, the most widely distributed triatomine in America, is a major threat in cities of this continent. The combination of strategies based on social housing, health education and vector control should work.

Protection of housing - Public and private housing construction plans should incorporate designs such as plastering walls, installing concrete floors and corrugated iron 


\section{TABLE III}

Diagnostic key points for oral transmitted Chagas disease

Simultaneity of similar symptoms among several persons.

Affected individuals who have shared food or beverage at the same time.

Exposure to handmade beverages in endemic areas.

Absence of clinical signs of parasite entrance (Romaña or Chagoma signs).

Laboratory screening for Chagas disease in long lasting high fever, facial or lower limb oedemas, decay, miocarditis and other unspecific symptoms (cough, abdominal pain etc).

Demonstration of motile Trypanosoma cruzi blood trypomastigotes in an acute outbreak, in spite of being asymptomatic patients.

Serological tests (specific IgM and IgG detection by ELISA) for the rapid screening of large groups of suspected infected individuals. Retrospective demonstration of concomitant symptoms in related individuals from a recent index chronic case of Chagas disease.

roofs that avoid the influx and domiciliation of triatomines and other pests (Briceño-León 1990, WHO 2010). The use of mosquito mesh in windows and doors is useful.

Rural population - Although an efficient program for the construction and improvement of rural housing was designed by the Ministry of Health in Venezuela, houses with palm roofs and adobe walls persist in rural areas. The presence of chickens and dogs on the periphery of the housing increases the attraction of triatomines on one hand, but on the other hand, their presence is a natural barrier because these vectors usually prefer to feed on the animals than on humans. In rural areas, maintaining the cleanliness of the peripheral area of the house, avoiding the presence of rodents and other animals, which are reservoirs of this parasitosis, is essential.

Urban population - The proximity of high mountains with dense vegetation around the cities (such as Caracas) limits the possible use of massive insecticides. Therefore, the only sustainable measures are improving housing and decreasing the attraction of triatomines (Reyes-Lugo 2009) caused by artificial light emitted by TVs and computers, which should be facing away from the windows.

Health education - Oral transmission converts Chagas disease into a food-borne disease. In this sense, prevention measures in both rural and urban areas should be addressed to raise awareness regarding the risk that infected triatomines and Didelphis can contaminate food with their droppings and secretions. Prepared food and beverages should not stay out of the fridge, particularly at night. Washing should be routine for fruits and vegetables. Utensils such as cups, blenders, cutlery and pots should be checked before use. In school cafeterias, traditional drinks should be substituted by pasteurised packaged beverages. Fruit beverages whose preparation is not supervised should not be consumed.

Medical education - The first reason for diagnostic failure is that most medical personal in public and private health centres rarely suspect Chagas disease. None of the ill individuals with mild or severe symptoms, even the most severe cases, during the febrile period were diagnosed properly during the early weeks. Even with pericardial effusion, Chagas disease was not considered an initial differential diagnosis. Some diagnostic key points are provided in Table III. Conferences, workshops and discussions aimed to make physicians aware of the existence of orally transmitted Chagas disease must be promoted in all endemic countries. Screening for Chagas disease must be performed in all patients with a persistent fever of unknown origin, myocarditis or pericarditis in endemic countries independent of triatomine knowledge, age, sex, occupation or social level. During the epidemiological investigation, other acute cases related to the index case should be searched and the group of individuals who could be exposed to the same source of infection and the possible day of infection (parties, meetings, Mother's or Father's Day, Carnivals, Easter and birthdays) should be investigated.

Orally transmitted Chagas disease transmission in Venezuela has occurred in schools and in small family groups, in the cities and in rural areas. In schools, the most affected group was young children. Elderly, children and pregnant or postpartum women accounted for the majority of the deceased. Therefore, the risk of acquiring Chagas disease through food and drinks is a new epidemiological reality all around the country, with an evident risk of death.

\section{ACKNOWLEDGEMENTS}

To the school authorities, personal, parents and students of the affected schools, to acute ill persons, for their confidence in our clinical and laboratory management, to Milagros Aponte and Eyleen Moronta, for their dedication to the patients, and to Dr Nestor Añez, for complementary information on Mérida outbreak.

\section{REFERENCES}

Alarcón de Noya B, Díaz-Bello Z, Colmenares C, Ruiz-Guevara R, Mauriello L, Zavala-Jaspe R, Suárez JA, Abate T, Naranjo L, Paiva M, Rivas L, Castro J, Márques J, Mendoza I, Acquatella H, Torres J, Noya O 2010a. Large urban outbreak of orally-acquired acute Chagas disease at a school in Caracas, Venezuela. J Infect Dis 201: 1308-1315.

Alarcón de Noya B, Díaz-Bello Z, Colmenares C, Ruiz-Guevara R, Noya O 2010b. Enfermedad de Chagas de transmisión oral: vinculación del caso índice con una microepidemia urbana en Venezuela. Bol Mal Salud Amb 50: 133-136.

Alarcón de Noya B, Díaz-Bello Z, Colmenares C, Zavala-Jaspe R, Abate T, Contreras R, Losada S, Artigas D, Mauriello L, RuizGuevara R, Noya O 2012. The performance of laboratory tests in the management of a large outbreak of orally transmitted Chagas disease. Mem Inst Oswaldo Cruz 107: 893-898. 
Alarcón de Noya B, Martínez J 2009. Transmisión oral de la enfermedad de Chagas en Venezuela: un segundo brote escolar. Salus 13: 11-20.

Alarcón de Noya B, Veas J, Ruiz-Guevara R, Martín A, Rojas C, Machado I, Telo C, Henao L, Díaz-Bello Z, Noya O 2013. Evaluación clínica y de laboratorio de pacientes hospitalizados durante el primer brote urbano de enfermedad de Chagas de transmisión oral en Venezuela. Rev Patol Trop 42: 177-186.

Alarcón de Noya BA, Colmenares C, Ruiz-Guevara R, Díaz-Bello Z, Noya O 2010c. La transmisión oral en la enfermedad de Chagas. Rev Fac Med 33: 78-86.

Alarcón de Noya BA, Díaz-Bello Z, Colmenares C, Muñoz A, RuizGuevara R, Balzano L, Campelo R, Abate T, Maniscalchi MT, Ramírez JL, Noya O 2011. Eficacia terapéutica en el primer brote de transmisión oral de la enfermedad de Chagas en Venezuela. Biomedica 31 (Suppl. 3): 64-65.

Añez N, Crisante G, Parada H 2007. Nuevos casos agudos de enfermedad de Chagas en el Occidente de Venezuela. Salus 11: 87-90.

Añez N, Crisante G, Rojas A, Dávila D 2013. Brote de enfermedad de Chagas agudo de posible transmisión oral en Mérida. Bol Mal Salud Amb 53: 1-11.

Añez N, Crisante G, Romero M 2009. Supervivencia e infectividad de formas metacíclicas de Trypanosoma cruzi en alimentos experimentalmente contaminados. Bol Mal Salud Amb 49: 91-96.

Beltrão HBM, Cerroni MP, Freitas DRC, Pinto AYN, Valente VC, Valente SA, Costa EG, Sobel J 2009. Investigation of two outbreaks of suspected oral transmission of acute Chagas disease in the Amazon Region, Pará state, Brazil, in 2007. Trop Doct 39: 231-232.

Benítez JA, Araujo B, Contreras K, Rivas M, Ramírez P, Guerra W, Calderón N, Terren CA, Barrera R, Rodríguez-Morales AJ 2013. Urban outbreak of acute orally acquired Chagas disease in Táchira, Venezuela. J Infect Dev Ctries 7: 638-641.

Bohórquez RMB, Blanco M, Nicholls S, Hernández C, Gualdrón L 1992. Estudio de una epidemia de carditis aguda en población adulta. Act Med Col 17: 4.

Briceño-León R 1990. La casa enferma: sociología de la enfermedad de Chagas, Fondo Editorial Acta Científica Venezolana, Caracas, $149 \mathrm{pp}$.

Cáceres DC, Nicholls RS, Corredor A, Gualdrón L, Slait E, Dib JC, Ariza K 1999. Investigación de un brote de síndrome febril con miocarditis aguda en Guamal, Magdalena. Inf Quinc Epidemiol Nac 4: 170-178.

Cardoso AVN, Lescano SAZ, Amato Neto V, Gakiya E, Santos SV 2006. Survival of Trypanosoma cruzi in sugar cane used to prepare juice. Rev Inst Med Trop Sao Paulo 28: 287-289.

Carrasco H, Segovia M, Llewellyn MS, Morocoima A, UrdanetaMorales S, Martínez C, Martínez CE, Garcia C, Rodríguez M, Espinosa R, Alarcón de Noya B, Díaz-Bello Z, Herrera L, Fitzpatrick F, Yeo M, Miles MA, Feliciangeli MD 2012. Geographical distribution of Trypanosoma cruzi genotypes in Venezuela. PLoS Negl Trop Dis 6: e1707.

Carrasco HJ, Torrellas A, García C, Segovia M, Feliciangeli MD 2005. Risk of Trypanosoma cruzi I (Kinetoplastida: Trypanosomatidae) transmission by Panstrongylus geniculatus (Hemiptera: Reduviidae) in Caracas (Metropolitan District) and neighboring states, Venezuela. Int J Parasitol 35: 1379-1384.

Castro JA, de Mecca MM, Bartel L 2006. Toxic side effects of drugs used to treat Chagas disease (American trypanosomiasis). Hum Exp Toxicol 25: 471-479.

Cavalcanti LPG, Rolim DB, Pires-Neto RJ, Vilar DCLF, Nogueira JOL, Pompeu MML, Teixeira MJ, Sousa AQ 2009. Microepidemics of acute Chagas disease by oral transmission in Ceará. Cad Saude Colet 17: 911-921.
Coura JR 2006. Transmission of chagasic infection by oral route in the natural history of Chagas disease. Rev Soc Bras Med Trop 39 (Suppl. 4): 113-117.

Díaz-Bello Z, Thomas MC, López MC, Zavala-Jaspe R, Noya O, Alarcón de Noya B, Abate T 2014. Trypanosoma cruzi genotyping supports a common source of infection in a school-related oral outbreak of acute Chagas disease in Venezuela. Epidemiol Infect 142: 156-162.

Díaz-Bello Z, Zavala-Jaspe R, Reyes-Lugo M, Abate T, Colmenares C, Noya O, Herrera L, Alarcón B 2011. Trypanosoma cruzimamíferos reservorios-Panstrongylus geniculatus: desde un foco zoonótico en un barrio urbano a la microepidemia de transmisión oral en una comunidad escolar de Caracas, Venezuela. Biomedica 31 (Suppl. 3): 278-279.

Diaz-Ungría C 1965. Transmisión del Trypanosoma cruzi en los vertebrados. Rev Iberica Parasitol 25: 1-44.

Duffy T, Cura CI, Ramirez JC, Abate T, Cayo NM, Parrado R, DíazBello Z, Velazquez E, Muñoz-Calderon A, Juiz NA, Basile J, Garcia L, Riarte A, Nasser JR, Ocampo SB, Yadon ZE, Torrico F, Alarcón de Noya B, Ribeiro I, Schijman AG 2013. Analytical performance of a multiplex real-time PCR assay using TaqMan probes for quiantification of Trypanosoma cruzi satellite DNA in blood samples. PLoS Negl Trop Dis 7: 1-11.

Freilij H, Muller L, González-Cappa M 1983. Direct micromethod for diagnosis of acute and congenital Chagas disease. J Clin Microbiol 18: 327-330.

Gascón J, Bern C, Pinazo MJ 2010. Chagas disease in Spain, the United Sates and other non-endemic countries. Acta Trop 115: 22-27.

Hernández LM, Ramírez A, Cucunubá Z, Zambrano P 2009. Brote de Chagas agudo en Lebrija, Santander, 2008. Rev Observat Sal Pub Santander 4: 28-36.

Herrera C, Guhl F, Falla A, Fajardo A, Montilla M, Vallejo GA, Bargues MD 2009. Genetic variability and phylogenetic relationships within Trypanosoma cruzi I isolated in Colombia based on mini-exon gene sequences. J Parasitol Res 2009: 9 pp.

Jansen AM, Deane MP 1985. Trypanosoma cruzi infection of mice by ingestion of food contaminated with material of the anal gland of the opossum Didelphis marsupialis. Proceedings of the Reunião sobre pesquisa básica em doenças de Chagas, 1985 Nov, Caxambu, p. 39.

Lainson R, Shaw JJ, Naiff RD 1980. Chagas disease in the Amazon Basin: speculations on transmission per os. Rev Inst Med Trop Sao Paulo 22: 294-297.

Luquetti AO, Rassi A 2000. Diagnóstico laboratorial da infecção pelo Trypanosoma cruzi. In Z Brener, ZA Andrade, M Barral-Netto (eds.), Trypanosoma cruzi e doença de Chagas, 2nd ed., Guanabara Koogan, Rio de Janeiro, p. 344-378.

Maguire JH, Hoff R, Sleigh AC, Mott KE, Ramos NB, Sherlock IA 1986. An outbreak of Chagas disease in southwestern Bahia, Brazil. Am J Trop Med Hyg 35: 931-936.

Martín A, Alarcón de Noya B, Montero R, Rojas C, Garrido E, RuizGuevara R, Díaz-Bello Z 2009. Epidemia de Chagas agudo adquirido por vía oral en una escuela de Caracas: descripción del caso índice. Arch Venez Puer Ped 72: 97-100.

Mazza S, Montana A, Benítez C, Janzi EZ 1936. Transmisión del Schizotrypanum cruzi al niño por leche de la madre con la enfermedad de Chagas. MEPRA 28: 41-46.

Miles MA 1972. Trypanosoma cruzi-milk transmission of infection and immunity from mother to young. Parasitology 65: 1-9.

Miles MA 2010. Orally acquired Chagas disease: lessons from an urban school outbreak. J Infect Dis 201: 1282-1284. 
Muñoz-Calderón A, Díaz-Bello Z, Valladares B, Noya O, López MC, Alarcón de Noya B, Thomas MC 2013. Oral transmission of Chagas disease: typing of Trypanosoma cruzi from five outbreaks occurred in Venezuela shows multiclonal and common infections in patients, vectors and reservoirs. Infect Genet Evol 17: 113-122.

Muñoz-Calderón A, Santaniello A, Pereira A, Yannuzzi J, Díaz-Bello Z, Alarcón de Noya B 2012. Susceptibilidad in vitro a nifurtimox y benznidazol de aislados de Trypanosoma cruzi obtenidos de pacientes venezolanos con enfermedad de Chagas infectados por mecanismos de transmisión oral y vectorial. Rev Ibero-Latinoam Parasitol 71: 14-22.

Nery-Guimarães F, Silva NN, Calusell DT, Mello AL, Rapone T, Snell T, Rodrigues N 1968. Um surto epidêmico de doença de Chagas de provável transmissão digestiva ocorrido em Teutônia (Estrela, Rio Grande do Sul). Hospital 73: 1767-1804.

Nóbrega AA, García MH, Tatto E, Obara MT, Costa E, Sobel J, Araújo WN 2009. Oral transmission of Chagas disease by consumption of açai palm fruit, Brazil. Emerg Infect Dis 15: 653-655.

Norman F, López-Velez R 2013. Chagas disease and breast-feeding. Emerg Infect Dis 19: 1561-1566.

OPS - Organización Panamericana de la Salud 2009. Guía para vigilancia, prevención, control y manejo clínico de la enfermedad de Chagas aguda transmitida por alimentos. Série de Manuales Técnicos 12, PANAFTOSA-VP/OPAS/OMS, Rio de Janeiro, 92 pp.

OPS/OMS - Organización Panamericana de la Salud/Organización Mundial de la Salud 2006. Estimación cuantitativa de la enfermedad de Chagas en las Américas. Available from: bvsops.org. uy/pdf/chagas19.pdf.

Pereira KS, Barbosa RL, Passos LAC, de Aguiar FS, Rogez H, Alarcón de Noya B, González ON 2013. Trypanosoma cruzi. In LJ Robertson, HV Smith (eds.), Foodborne protozoan, Nova Science Publishers, Norway, p. 189-216.

Pinto AYN, Valente SAS, Valente VC, Ferreira Jr AG, Coura JR 2008. Fase aguda da doença de Chagas na Amazônia brasileira. Estudo de 233 casos no Pará, Amapá e Maranhão observados entre 1988 e 2005. Rev Soc Bras Med Trop 41: 602-614.

ProMED 2010a. Trypanosomiasis, foodborne - Venezuela: Caracas. Available from: promedmail.org.

ProMED 2010b. Enfermedad de Chagas, oral, brote - Colombia (Cesar). Available from: promedmail.org.

ProMED 2012. Enfermedad de Chagas oral, brote, trabajadores de mercado de alimentos - Venezuela (Caracas). Available from promedmail.org.

ProMED 2014. Enfermedad de Chagas - Colombia (CAS): transmisión oral, brote. Avalilable from: promedmail.org.

Rassi Jr A, Rassi A, Marin-Neto JA 2010. Chagas disease. Lancet 375: 1388-1402.

Reyes-Lugo M 2009. Panstrongylus geniculatus Latreille 1811 (Hemiptera: Reduviidae: Triatominae), vector de la enfermedad de Chagas en el ambiente domiciliario del centro-norte de Venezuela. Rev Biomed 20: 180-205.

Ríos JF, Arboleda M, Montoya AN, Alarcón EP, Parra-Henao GJ 2011. Probable outbreak of oral transmission of Chagas disease in Turbo, Antioquia. Biomedica 31: 185-195.

Roellig DM, Ellis AE, Yabsley MJ 2009. Oral transmission of Trypanosoma cruzi with opposing evidence for the theory of carnivory. J Parasitol 95: 360-364.

Santalla-Vargas S, Oporto P, Espinosa E 2011. Primer brote reportado de la enfermedad de Chagas en la Amazonia boliviana: reporte de 14 casos agudos por transmisión oral de Trypanosoma cruzi en Guayaramerín, Beni-Bolivia. Biofarbo 19: 52-58.

Schijman AG, Bisio M, Orellana L, Sued M, Duffy T, Mejia-Jaramillo AM, Cura C, Auter F, Veron V, Qvarnstrom Y, Deborggraeve S, Hijar G, Zulantay I, Lucero RH, Velazquez E, Tellez T, León ZS, Galvão L, Nolder D, Rumi MM, Levi JE, Ramírez JD, Zorrilla P, Flores M, Jercic MI, Crisante G, Añez N, de Castro AM, González CI, Viana KA, Yachelini P, Torrico F, Robello C, Diosque P, Chávez OT, Aznar C, Russomando G, Büscher P, Assal A, Guhl F, Estani SS, da Silva A, Britto C, Luquetti A, Ladzins J 2011. International study to evaluate PCR methods for detection of Trypanosoma cruzi DNA in blood samples from Chagas disease patients. PLoS Negl Trop Dis 5: e931.

Shikanai-Yasuda MA 1987. Surto epidêmico de doença de Chagas aguda em Catolé do Rocha, Paraíba. Rev Soc Bras Med Trop 20 (Suppl. 2): M14-M16.

Steindel M, Pacheco LK, Scholl D, Soares M, de Moraes MH, Eger I, Kosmann C, Sincero TC, Stoco PH, Murta SM, de Carvalho-Pinto CJ, Griscard EC 2008. Characterization of Trypanosoma cruzi isolated from humans, vectors and animal reservoirs following an outbreak of acute human Chagas disease in Santa Catarina state, Brazil. Diagn Microbiol Infect Dis 60: 25-32.

Suárez J, de Suárez CB, Alarcón de Noya B, Espinosa R, Chiurillo MA, Villaroel PA, de Martín F, Paiva M, Díaz-Bello Z, Valderrama E, Estrada D, Vivas E 2010. Enfermedad de Chagas sistémico en fase aguda por transmisión oral: diagnóstico integral de un caso autopsiado. Gac Med Caracas 118: 212-222.

SVS - Secretaria de Vigilância em Saúde 2011. Aspectos epidemiológicos - casos de doença de Chagas aguda, 2000-2010. Available from: portal.saude.gov.br/portal/saude/profissional/visualizar_texto.cfm?idtxt531454.

Thomas ME, Rasweiler IV JJ, D’Alessandro A 2007. Experimental transmission of the parasitic flagellates Trypanosoma cruzi and Trypanosoma rangeli between triatomine bugs or mice and captive Neotropical bats. Mem Inst Oswaldo Cruz 102: 559-565.

Valente SAS, Pimentel PS, Valente VC, Pinto AYN, Souza GCR, Carvalho LS 2001. Microepidemia familiar de doença de Chagas em Santarém. Primeiro registro no oeste do Pará. Rev Soc Bras Med Trop 34 (Suppl. 1): 19-20.

Valente SAS, Valente VC, Fraiha Neto H 1999. Considerations on the epidemiology and transmission of Chagas disease in the Brazilian Amazon. Mem Inst Oswaldo Cruz 94 (Suppl. I): 395-398.

Valente SAS, Valente VC, Pinto AYN, Barbosa CMJ, dos Santos MP, Miranda COS, Cuervo P, Fernandes O 2009. Analysis of an acute Chagas disease outbreak in the Brazilian Amazon: human cases, triatomines, reservoir mammals and parasites. Trans $R$ Soc Trop Med Hyg 103: 291-297.

WHO - World Health Organization 2007. Consultation on international biological reference preparations for Chagas diagnostic tests, WHO, Geneva, $25 \mathrm{pp}$.

WHO - World Health Organization 2010. Working to overcome the global impact of neglected tropical diseases: first WHO report on neglected tropical diseases, WHO, Geneva, 184 pp.

Xavier SCC, Roque ALR, Bilac D, de Araújo VAL, Neto SFC, da Silva LFC, Jansen AM 2014. Distantiae transmission of Trypanosoma cruzi: a new epidemiological feature of acute Chagas disease in Brazil. PLoS Negl Trop Dis 8: e2878.

Zingales B, Miles MA, Campbell DA, Tibayrenc M, Macedo AM, Texeira MMG, Schijman AG, Lewellyn MS, Lages-Silva E, Machado CR, Andrade SG, Stum NR 2012. The revised Trypanosoma cruzi subspecific nomenclature: rationale, epidemiological relevance and research applications. Infect Genet Evol 12: 240-253. 